\title{
ІНТЕРНОВАНІ ВОЯКИ УГА В ТАБОРІ ЙОЗЕФОВ (ЧЕХОСЛОВАЧЧИНА) У 1921-1922 РР.: УМОВИ ПЕРЕБУВАННЯ ТА САНІТАРНИЙ СТАН
}

\author{
I. В. Срібняк
}

Срібняк I. В. Інтерновані вояки УГА в таборі Йозефов (Чехословаччина) у 1921-1922 рр.: умови перебування та санітарний стан. У статті розкрито особливості перебування інтернованого вояцтва УГА в таборі Йозефов, їх настрої, деякі аспекти приватного життя таборян, стан здоров'я, побут тощо. Використані документи дають змогу зануритись в атмосферу табору та досить повно відтворити «затемнені» сторінки таборового повсякдення. Проаналізовано ставлення чехословацької влади до інтернованого вояцтва УГА, яка з одного боку залишалась вірною своїм зобов'язанням 3 його утримання, а $з$ іншого намагалась ліквідувати табір в Йозефові, а його мешканців перевести на цивільний стан.

Ключові слова: табір інтернованих; комендатура; старшини УГА, Чехословаччина.

Срибняк И. В. Интернированные воины УГА в лагере Йозефов (Чехословакия) в 19211922 гг.: условия пребывания и санитарное состояние. В статье раскрыты особенности пребывания интернированных офицеров и солдат УГА в лагере Йозефов, их настроения, некоторые аспекты частной жизни, состояние их здоровья, быт и др. Использованные документы дают возможность углубиться в атмосферу лагеря и достаточно полно реконструировать «затемненные» страницы лагерной повседневности. Проанализировано отношение чехословацкой власти к интернированным воинам УГА, которая с одной стороны оставалась верна своим обязательствам по их содержанию, а с другой предпринимала попытки ликвидировать лагерь в Йозефове, а его обитателей перевести на цивильное положение.

Ключевые слова: лагерь интернированных; комендатура; офицеры УГА; Чехословакия.

Sribnyak I. V. UGA Interned Soldiers in the Josefov Camp (Czechoslovakia) in 1921-1922: Conditions of Stay and Sanitary. The article reveals peculiarities of stay of interned officers and soldiers in the camp Josefov UGA, their moods, some aspects of private life, their health, life and others. The historical douments make it possible to delve into the atmosphere of the camp and adequately reconstruct the ««blackout» of the page of the camp daily. An analysis is made of the attitude to the Czechoslovak authorities to the interned soldiers UGA, which, of on one hand, remained true to its commitments on their content, but on the other hand, attempted to liquidate the camp in Josefov and to transfer its inhabitants to the position of civilian people.

Keywords: internment camp; the commandant's office; UGA officers; Czechoslovakia.

Початок науковому опрацюванню даної теми поклала публікація у 1942 р. книги С. Наріжного «Українська еміграція», без якої сьогодні не може обійтися жоден дослідник табірної тематики й споріднених з нею проблем ${ }^{1}$. Автор проаналізував різні аспекти культурно-просвітницької діяльності українського вояцтва, інтернованого у таборах Польщі та Чехословаччини, водночас він не ставив собі за мету здійснення докладного аналізу таборового повсякдення інтернованих вояків-українців у ЧСР. Публікація видавництвом ім. O. Теліги другої частини монографії С. Наріжного суттєво доповнила наші уявлення про окремі прояви життєдіяльності таборян у ЧСР, але внаслідок того, що автор не закінчив роботи над рукописом цієї книги, майже всі іiі матеріали мають фрагментарний характер і не дають цілісного бачення досліджуваної проблемиㄹ․

Значно активізувалась робота з вивчення таборового життя вояків-українців у кінці 90-х рр. ХХ ст. Так, зокрема, історик М.І. Павленко впродовж 1998-1999 рр. опублікував близько 20 статей, в яких проаналізував окремі аспекти перебування полонених та інтернованих українців у таборах Польщі, Чехословаччини і Румунії у 1919-1924рр. Практичні всі ці матеріали увійшли до виданої ним у 1999 р. монографії ${ }^{3}$, яка стала підсумком його дослідницької роботи за два згадувані роки, а роком пізніше ії̈ текст був представлений автором у вигляді дисертації доктора історичних наук.

Основний напрям його дослідження полягав, зокрема, у відтворенні ставлення урядів вказаних у назві країн, а також Москви до проблеми полонених та інтернованих вояківукраїнців, у висвітленні перебігу політичної боротьби у середовищі українського вояцтва

(C) Срібняк, I. В., 2015 
та розкладової діяльності у таборах більшовицьких агентів, у дослідженні процесу репатріації інтернованих до радянської Росії. Але попри цілий розділ монографії, присвячений ситуації в таборах УГА в ЧСР, М. Павленко майже нічого не повідомляє про таборове повсякдення інтернованих в Йозефові, відсутні також і сюжети про побутові умови їх проживання у цьому таборі.

До вивчення даної тематики у цей час звертався й автор даної публікації, який у низці статей та монографії зосередився на вивченні особливостей культурно-освітньої роботи в таборах УГА в ЧСР, у т.ч. й в Йозефові ${ }^{4}$, тобто умови таборового існування українського вояцтва у згадуваному таборі не були висвітлені жодним зі згаданих дослідників. Такий стан справ був визначальною мірою обумовлений тим, що ані М. Павленко, ані І. Срібняк не мали можливості скористатись дотичними до цієї теми матеріалами, які зберігались у фонді 269 Центрального державного архіву громадських об'єднань України (ЦДАГО України). 3 моменту їх отримання архівом у 1988 р. і до 2008 р. вони були закриті для переважної більшості дослідників його директором В. С. Лозицьким, який щоправда мав на той час всі підстави для цього через їх розпорошеність та відсутність описів (за таких умов архівні справи не видаються дослідникам).

Робота 3 їх упорядкування тривала неадекватно довго - цілих два десятиліття, попри те, що згадуваний архів диспонував достатніми науковими силами (у цьому контексті доречно згадати про досвідченого архівіста А.В. Кентія) та значними ресурсами для їх упорядкування (про це свідчить виготовлення якісної резервної копії фонду 269). Зрештою, причиною такої пролонгації було те, що за ініціативою директора в архіві тривали підготовчі заходи до видання збірки документів ${ }^{5}$, відтак доступ до ф. 269 довгі роки мали лише «наближені особи» до керівника групи упорядників (він же - директор архіву). I тільки вихід у світ «доленосної» збірки і задоволення в такий спосіб науково-архівних амбіцій добродія В. Лозицького дозволив решті дослідників доступитися потрібних архівних документів та поновити наукові студії з табірної проблематики. Слід також додати, що у згадуваній збірці документів представлені лише чотири короткі документи (№№ 45, 64, $69,88)$, які стосуються таборової проблематики, але ж, очевидно, що не дають цілісного уявлення про життя та побут інтернованих в Йозефові (з них лише перший датований липнем 1922 р., решта - пізнішими роками $)^{6}$.

Щоправда, сучасні дослідники таборової тематики у своїй переважній більшості не поспішають скористатись своїм шансом та не виявляють зацікавлення до вивчення цих архівних документів, воліючи публікувати значною мірою описові матеріали. Це твердження, зокрема, стосується двох статей, які хоч і були присвячені культурно-освітньому та національно-патріотичному аспектам таборового повсякдення вояків УГА, тим не менш містять лише поодинокі посилання на архівні матеріали ЦДАВО України і можуть претендувати (як за своїм обсягом, так і рівнем опрацювання даної тематики) тільки на статус нотаток до даної дослідницької проблеми․

Пропонована стаття майже цілком сперта на матеріалах двох архівних справ згадуваного фонду, в яких зібрана значна кількість рапортів та повідомлень української команди табору Йозефов, адресованих військовому відпоручнику Диктатора ЗУНР С. Петрушевича або його військової канцелярії. Вони дозволяють досить повно відтворити дійсне становище таборян, їх настрої, деякі аспекти приватного життя інтернованих, стан їх здоров'я, особливості побуту тощо. Більше того, ці документи дають змогу зануритись в атмосферу табору та досить повно відтворити «затемнені» сторінки таборового повсякдення, деякі 3 яких ніколи не афішувались ані командою таборі, ані загалом інтернованих.

$$
* * *
$$

Вояки-українці опинялись на теренах Чехословацької республіки в різний спосіб частина з них зі зброєю в руках була змушена відступити до іiі меж під тиском польської армії у 1919 р., решта прибула (як втікачі або репатріанти) з Італії та інших європейських країн у 1919-1920 pр. Ці дві категорії галичан утримувались спочатку в різних таборах Німецькому Яблонному та Ліберцях, але у 1921 р. всі вони були скупчені в двох окремих секціях одного табору Йозефов. Умови таборового існування інтернованих вояків УГА суттєво різнились в залежності від пори року, причому особливо у тяжкому становищі таборяни опинились взимку. 
Справа в тім, що інтерновані розміщувались у тимчасових, непристосованих для холодної пори року бараках, при цьому чехословацька влада не вважала за доцільне витрачати кошти на їх утеплення та облаштування. Особливо це стосувалось табору в Йозефові, де українських вояків (а також жінок і дітей) було розміщено в бараках, в яких перед цим перебували полонені червоноармійці. Зрозуміло, що офіційна Прага, усвідомлюючи тимчасовість утримання тут як полонених росіян, так й інтернованих українців, майже не переймалась підтриманням фізичного стану бараків, які фактично вже не надавались для проживання в них людей.

Після прийняття на початку березня 1921 р. чехословацькою владою рішення про ліквідацію табору в Ліберцях вже наступного місяця було розпочато передислокацію інтернованих у ньому вояків УГА до «Українського Військового Табора в Йозефові». Оцінюючи санітарно-побутову ситуацію на новому місці перебування, комендант табору (на той час) майор Роман Волощук у своєму рапорті (ч.1/к від 6 квітня 1921 р.) до Військового Відпоручника Диктатора ЗУНР у Празі відзначав набагато гіршу якість бараків в Йозефові (у порівнянні з Ліберцями), що унеможливлювало, на його думку, перебування в них взимку. Дуже незручним було розташування вікон - «високо під стелею, малі, $1 \frac{2}{2}$ метра високі, $1 \frac{1}{2}$ метра широкі, зависоко аби через них дивитись можна». Тривалий час бараки (кількістю - 28) стояли зачиненими, бо тут була «переходова збірна станиця» 3 перемінним складом, відтак не було потреби їх всі використовувати ${ }^{8}$.

3 метою підготовки бараків до розселення інтернованих до Йозефова були надіслані квартир'єри з числа таборян, проте комендант табору полковник Залєський довший час не допускав їх до роботи. Між тим іï було безліч, бо в усіх бараках залишався «великий бруд, ще кількалітній, який грубою верствою покриває всі підлоги». Цілком незадовільним було й електричне освітлення (точніше його майже повна неефективність): коли кожен барак під самою стелею освітлювала одна лампа на 10 вольт, зрозуміло, що при такому освітленні не була можливою жодна робота, натомість чехословацька комендатура не погоджувалась на будь-яке переобладнання електрики чи пониження ламп 3 міркувань економії

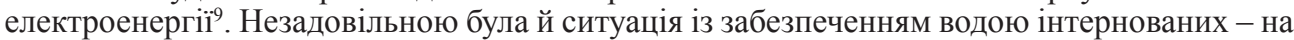
території сектору «Б» була лише одна криниця, вода подавалась лише до двох бараків, але й в них водогони відключались на кілька годин після обіду.

Майор Р. Волощук повідомляв, що в таборі величезна кількість щурів, і якщо не вжити заходів, вони можуть стати справжньою бідою для таборян. Ця «незручність» доповнювалась тим, що «всі деревляні причі (лежаки - I. С.), на яких спить стрілецтво, повні блощиць». Нарешті, в жодному з бараків не було облаштованих туалетів, натомість інтерновані мали користуватись кількома спільними масовими «лятринами» (власне, відкриті ями з примитивними конструкціями для задоволення природних потреб - I. С.). Видається зайвим наголошувати на тому, що така «система» для використання жінками та дітьми цілком не надавалась ${ }^{10}$.

Багато хто з інтернованих, дізнавшись в різний спосіб про санітарну ситуацію в Йозефові, відмовлявся від переїзду, так що транспорти до табору йшли на $1 / 4$ незаповненими. İ лякала непристосованість бараків до перебування в них влітку, тоді що ж говорити про проживання в них в зимовий період ${ }^{11}$. Таборяни мали всі підстави максимально відтягувати день переїзду, бо потрібний матеріал для переобладнання бараків чехословацька комендатура виділяла «дуже скупо», зокрема вона спромоглась надати лише «дошки 3 розібраних двох бараків в сусіднім більшовицькім таборі, до того поржавілі старі цвяхи зі старих дощок». Наступним «подарунком» комендатури для інтернованих стали кілька щіток для побілки та підмітання підлоги, «3 пили, 2 молотки та дещо старих цвяхів». Всі прохання інтернованих звернутись 3 клопотанням про отримання хоч мінімальних коштів 3 бюджету Міністерства народної оборони ЧСР вперто ігнорувались комендантом табору полковником Залєським ${ }^{12}$.

Взагалі, чехословацький комендант намагався зекономити на усьому - навіть на воді, дорікаючи таборянам у тому, «що 120 українців зуживає більше води, ніж 2000 полонених Москалів», але перевитрата води пояснювався тим, що таборяни мусіли «мити всі підлоги в цілім таборі, всі вікна та прочу брудну обстановку». Знаючи про великий обсяг робіт, які мали виконати інтерновані старшини УГА, чехословацька комендатура запропонувала використовувати для прибирання полонених червоноармійців з секції «Д», але їх робота була настільки малоефективною, що Р. Волощук майже відразу відмовився від їх «допомоги»13. 
Внаслідок всього цього бараки переобладнувались дуже повільно, робота тривала лише у двох з них, які призначались для булавних та одружених старшин та підстаршин. Ці бараки були поділені на невеликі кімнатки, а також обладнані зручніші вікна та вставлені двері. Тривалий час ці кімнати не мали ані ліжок, ані жодних інших меблів, які мали бути перевезені з Ліберець, але через неквапливість чехословацької влади надовго там «застрягли». В цій ситуації комендатура табору «пішла на зустріч» першим поселенцям табору і запропонувала їм дерев'яні лежаки з набитими соломою матрацами, якими раніше користувались полонені червоноармійці, але без жодної постільної білизни. Це викликало цілком справедливе обурення та спонукало чехословацьку комендатуру все ж таки видати українським старшинам 120 залізних стрілецьких ліжок без матраців, а на решту меблів та речей чекати з Ліберецького табору, хоч цей процес міг зайняти 2-3 місяці ${ }^{14}$.

Всі старшини та підстаршини були змушені власноруч займатись приведенням своїх кімнаток до хоч би мінімального рівня комфорту, наскільки це було можливим у таборових умовах. Вони самотужки відмивали «роками засвижену [...] майже центиметровою верствою болота покриту підлогу» та були змушені «дерти при тім послідній протертий вже мундир». Більше того, через відсутність коней «мусять члени табора тягнути віз руками, хотячи привезти чи речи 3 двірця (залізничного вокзалу - I. С.) чи будівельний матеріял 3 сусіднього табора» ${ }^{15}$.

Харчування інтернованих в Йозефові забезпечувалось «далеко гірше» у порівнянні 3 Ліберецькими табором через відсутність своєї «Зарядчої Комісії» та т.зв. харчового старшини, які були би уповноважені контролювати чехословацьких інтендантів. Так само була відсутній «табель харчових належностей», який регламентував би щоденну видачу продуктів для інтернованих. За його відсутності таборянам видавали «фасолю, горох, риж (рис - aвm.), м'ясо або м'ясну консерву та кунероль чи маргарину, від якої деякі старшини вже нездорові. [...] Вечером лиш чорна кава». За таких умов було неможливим організувати роботу старшинської їдальні, тому «всі члени табора харчуються з одної спільної кухні» ${ }^{16}$.

Хоча табір в Йозефові мав будуватись на тих самих засадах, як перед цим у Ліберцях (інтерновані підлягали власній команді табору, яка мала право застосовувати дисциплінарні покарання та діяти у порозумінні з чехословацькою комендатурою), проте фактично автономні права української військової влади були звужені, зокрема вона не могла контролювати якість та норми видачі продуктів, що призначались для приготування їжі для вояцтва. Полковник Залєський також відмовив у отриманні «релютуму» (видачі грошей замість пайку - aвm.) для тих старшин УГА, які за станом здоров'я потребували спеціального харчування, заявивши, що «хворі належать до лічниці, а здорові мають їсти сей харч, який їм дається». Наразі автономія табору, іронізував Р. Волощук, виявляється в тому, що довкола нього висока дротяна огорожа та пости чехословацьких вартових, а вихід інтернованих поза межі табора обмежений чотирма годинами пополудні. Таким чином, робить висновок Р. Волощук, «ціла наша «автономія» не богато ріжниться від автономії сусідного большевицького табора «Д», хиба що у нас вихід поза таборову огорожу пересунений о 2 години пізніше» ${ }^{17}$.

Місцеве населення ставилось до інтернованих досить прихильно, особливо після того, як поволі навчилось відрізняти їх від полонених червоноармійців. Чехословацькі солдати досить часто демонстрували знаки воїнської поваги до інтернованих українських старшин, хоча через відсутність у декого з них нарукавних ступеневих відзнак ускладнювало справу розрізнення військових звань. Така ситуація була обумовлена тим, що багато старшин на мало коштів для придбання відповідних офіцерських відзнак.

На думку Р. Волощука, на таборовий загал деморалізуюче впливали ті члени табору, які студіювали у вищих навчальних закладах Праги, і з'являлись тут лише у вихідні дні. Їх щотижневий масовий виїзд на навчання мав «шкідливий вплив на незорієнтоване про [цю] справу стрілецтво та стягав на власну команду табора підозренє (підозру - I. С.) якихсь тайних махінацій та непорадності на своїм становиську». 3 огляду на це український комендант табору просив «застановити їх дальше прибуванє до табора, при чім команда табора подасть своєчасно до відома, коли можна буде їх приїзд в цілі поновного прийняття в стан» ${ }^{18}$.

На переконання Р. Волощука, виправити ситуацію в таборі могло би надходження коштів $з$ рахунків Міністерства народної оборони ЧСР для «адаптації» бараків, створення власної «Зарядчої Комісії» та виплати «релютів», що дозволило би закупати «якийсь зно- 
симий відповідний харч, без маргарини та консервованого м'яса», і нарешті організувати максимальне швидке перевезення з Ліберців «кімнатного та канцелярійного урядження», бо інтерновані в таборі через це не мають навіть мінімальних зручностей та можливості вести поточну роботу в таборі.

Він також пропонував зобов'язати коменданта табору в Ліберцях майора Мацейовича провести скорішу його ліквідацію та передати все державне майно до військових складів. Натомість все устаткування, яке було придбане на українські гроші (друкарські машинки, копіювальні машини, ремісничі прилади, запаси взуття та одностроїв), мало бути негайно перевезене до Йозефова. I зовсім нереалістично звучали дві останні пропозиції українського коменданта щодо того, аби «вистаратись у Чехів певної кількості одностроїв, в заміну за ті, які знищилися і ще знищаться», та знайти кошти для закупівлі відповідної кількості матеріалу для виготовлення старшинських та підстаршинських відзнак ${ }^{19}$. Українське командування інтернованих вживало всіх можливих заходів, намагаючись переконати чехословацького коменданта піти на зустріч проханням таборян, але полковник Залєський не погоджувався на будь-яку «найменшу зміну чи полекшу, на яку не мав ще виразної інструкції чи приказу від вищих властей».

Завершував свій рапорт комендант повідомленням про зменшення обсягу щоденного грошового утримання інтернованих, яке настало 5 квітня 1921 р. (на підставі розпорядження Міністерства народної оборони ЧСР від 4 жовтня 1920 р.). Згідно до нього всім працюючим таборянам відтоді встановлювалась денна оплата за роботу в розмірі 2,50 Кс̆ (крон чехословацьких) - замість 3 Кс̌, як було раніше). Крім цього всі інтерновані (у т.ч. жінки та діти) отримували ще 0,5 Кс̌ денно та 3,5 Кс̌ одноразової допомоги. Таке рішення чехословацької влади «викликало оправдане велике негодованє серед членів табора» ${ }^{20}$, бо змушувало таборян додатково обмежити свої потреби, які й без цього задовольнялись на мінімальному рівні.

Проте побутова ситуація в таборі поволі поліпшувалась, і попри тривожні рапорти українського командування інтерновані облаштовувались на новому місці, хоч і 3 мінімальними зручностями. Найголовнішою обставиною, яка сприяла цьому, була тепла пора року, погода поліпшувалась, харчове забезпечення таборян було достатнім, попри нарікання окремих старшин на його «недієтичність». Про це свідчить і рапорт коменданта «Українського військового табору в Йозефові» полковника А. Вольфа команді Української Бригади в Німецькому Яблонному від 10 травня 1921 р., в якому він, характеризуючи побутові обставини в таборі, занотував: «дуже далекі від добрих, одначе з кожним днем можливіші». Комендант відзначив, що забезпечення пайком інтернованих відбувається на рівні з чехословацькими солдатами, грошове забезпечення не виплачується, видаються тільки харчі, нарешті - кожному старшині денно видавалось 3,5 цигарки. I хоча раціон і харчування інтернованих старшин не відрізняється від стрілецького, воно забезпечувало прийнятні умови існування у таборі ${ }^{21}$.

Також у своєму рапорті А. Вольф спростовує поголоски про поширення дезертирства в таборі, зазначаючи, що з моменту переїзду інтернованих з Ліберців табір в Йозефові самовільно залишило 12 старшин, 6 підстаршин і 4 стрільці. 3 них 9 старшин виїхали на студії до Праги, де вони перебували й перед цим - за неофіційною згодою команди ліберецького табору. Взагалі, на думку А. Вольфа, на цю категорію вояків не слід зважати, бо це фактично цивільні особи, які були приміщені до табору з метою отримання допомоги та харчового забезпечення. Ще один старшина отримав призначення на цивільну посаду, i лише один старшина (з Наддніпрянщини), який знаходився під судовим слідством, втік у невідомому напрямку. Отже, робив висновок полковник А. Вольф, випадки дезертирства $\epsilon$ поодинокими і не являли жодної загрози українській військовій організації в таборі ${ }^{22}$.

Хоча насправді кількість старшин, які залишили табір у Ліберцях під час його ліквідації з метою завершення розпочатих студій, була значно більшою. 3 харчового забезпечення у згадуваному таборі було знято 108 старшин, з яких 58 були приписані до робітничого куреня УГА в Празі, 20 - до другого полку в Німецькому Яблонному, а ще 30 старшин залишились без жодного забезпечення. Між тим, це було лише тимчасовим вирішенням цієї проблеми, бо навіть приписані старшини мали бути відряджені до Йозефова, де могли регулярно отримувати свій щоденний пайок ${ }^{23}$.

Водночас у згадуваному рапорті йдеться про низький моральний стан у частини старшин, які поводяться збайдужіло та цілком інертно, не витримуючи всіх життєвих випро- 
бувань. Це обумовлювалось все меншими надіями на справедливе державно-правне вирішення долі ЗУНР та «невідрадне матеріяльне положення», яке «відбивається вельми некорисно на їх моральнім і фізичнім стані». До того ж, переважна більшість старшин УГА «так лихо вдягнені, що не можуть показуватись на вулицю. [...] Рівнож недостача обуви відчувається сильно». Очевидно, що відсутність одностроїв та неможливість їх придбати негативно впливали на настрої українського старшинства, дехто потерпав через малу норму пайку на паління (3,5 цигарки). Прохання ж старшин дозволити їх купувати 10 «папірос» денно за військовими (тобто некомерційними - I. С.) цінами не було задоволено. Все ж таки, на думку полковника А. Вольфа, переїзд до Йозефова мав позитивні наслідки для старшинського корпусу, бо кілька старшин, які маючи «багато свояків» у околицях Ліберців, «вели там гуляче життя», а зараз позбавлені такої можливості ${ }^{24}$.

Інтерновані все ще очікували на перевезення ліжок з Ліберців, після чого, на думку полковника А. Вольфа, табір в Йозефові цілком надавався би для побуту влітку, проте взимку - без його перебудови - існувати в ньому буде неможливо. За спостереженнями А. Вольфа, чехословацький комендант табору полковник Залєський прихильно ставиться до українців, але може дріб'язково втручатись до таких справ, які ніяким чином не можуть бути в його компетенції (як то організаційний поділ інтернованих українських військ). Тим не менш, якщо все в таборі залишатиметься без змін на краще, влітку слід рахуватись «навіть 3 численнішою дезерцією стрілецтва, з поміж якого більшість оставили дома газдівство (господарство - I. С.), що його тепер нема кому вести» ${ }^{25}$.

Все ж таки прихід теплої пори року не заспокоїв українську команду табору, яка добре усвідомлювало всю потенційну небезпеку перебування вояцтва УГА в непристосованих до морозів бараках. Вже на початку літа 1921 р. перший ад’ютант українського коменданта табору сотник I. Козак звернувся з «довірочним» рапортом (ч. 279 від 19 червня 1921 р.) до Військової канцелярії Диктатора ЗУНР у Відні, інформуючи його про стан готовності табору до зими. У своєму рапорті він висловив думку, що перебути зиму інтернованим в таборі «в Йозефові без основної адаптації, згл[ядно] цілковитої перебудови (підкреслено в тексті - I. C.) на зимівлю без поважного загроження життя і здоровля в нім приміщених осіб не надається» 3 огляду на цілу низку несприятливих обставин. По-перше, цілковита непристосованість бараків, які мали занадто тонкі стіни, а «дах до тої степени діравий, що нема ані одного бараку, який би в кількох місцях не протікав, двері і вікна [...] є зовсім примітивні та не пристають, так що всюди є щілини, крізь які продуває вітер» ${ }^{26}$.

I хоча чехословацькою комендатурою було прийнято розпорядження про проведення ремонту бараків до кінця травня, цього не було зроблено через відсутність матеріалу для ремонту та невиплату коштів майстрам, які це мали поладнати. Зрештою, на ремонт не вистачило би жодних коштів, бо «стан бараків $\epsilon$ так лихий, що їх адаптація згл[ядно] приспособлення на зимівлю не оплачується».

По-друге, сотник I. Козак також звертав увагу Військової канцелярії на те, що «ізза перебутих воєнних трудів та невзгодин під час війни на Україні та таборового життя, старшини і стрілецтво табора $є$ виснажені фізично і морально, а тим самим дуже вражливі на студінь (застуду - I. С.) і позбавлені всякої відпорности на хвороби» ${ }^{27}$. До того ж у середині червня в таборі поширилась пошесть «куриної сліпоти», яка виявлялась в тому, що людина втрачала здатність бачити 3 настанням сутінок (у таборі було зареєстровано 8 таких випадків). Причиною цього, на думку місцевого лікаря, було «перетомлення та лихе відживлювання». Ще троє таборян страждали на нервові розлади, що були наслідком «баракової психози, спонуканої моральною непевністю та мелянхолією». Вони проявлялись в такий спосіб, що «особа в певних хвилях тратить зовсім власть над своїми змислами та виглядає і поводиться наче божевільним. По якімсь часі приходить назад до себе» ${ }^{28}$.

Значна частина таборян потерпала «на катар і инші грудні недуги, при яких ліченню в першу чергу потрібна добра віджива і відповідне приміщення». Сотник I. Козак попереджав, що у тому випадку, коли би утеплення бараків не було проведене, належиться «належить числитись 3 тим, що всі грудні недуги переміняться в туберкулу». При цьому у рапорті він згадував про сумну долю близько 17 тис. полонених росіян в часі Першої світової війни, які «зараз похоронені на тут[ешньому] кладовищі» ${ }^{29}$.

3 великим сарказмом він також повідомляв про те, що чехословацька комендатура табору спостерігала «з великою дбайливістю» за тим, «щоби пайки, призначені для українських інтернованих, ані на волос не були переступлені». Норма вугілля для опалювання 
бараків була настільки мала (388 грам вугілля на чоловіка денно та 50\% додатково для бараків), що ії вистачило хіба що на обігрів «мурованої хати». Докуповувати вугілля неможливе через повну відсутність коштів, «а иншого матеріялу, якого би потайки мож[на] було на сю ціль ужити, тут нема також, впрочім хоч би й був, то чсл. команда пильнувала б його як ока в голові» ${ }^{30}$.

3 огляду на такий стан табору в рапорті йшлося про доцільність переміщення табору в інше місце, до військових казарм (приміром до Липника на Моравії, де за австрійських часів був карантин для хворих), причому таке переміщення мало відбутись влітку, бо «восени серед дощу і студени» транспортувати чоловіків, а також жінок і дітей є досить виснажливим для їх здоров'я, а крім того - кожен табір «потребує певного приготовлення на зимівлю, якого чеська влада зовсім певно без співучасті майбутніх мешканців табора не переведе $»^{31}$.

Проте всі звернення командування інтернованих про переведення таборян до забезпечених утепленими приміщеннями таборів не були почуті чехословацькою владою. Більше того, до Йозефова у липні 1921 р. прибула група колишніх полонених українців з Італії (з табору Лібрінг), яка чехословацькою владою «уважалась військовою частиною нарівні 3 українськими частинами, перейшовшими границю чсл. (Чехословацької - I. С.) Республіки 3 оружжям в руках» ${ }^{32}$. А в середині серпня 1921 р. чехословацька влада ухвалила рішення про поступове переведення сюди Української Бригади з Німецького Яблонного 33 .

Відтак інтернованим довелось організовувати свій побут в Йозефові на довший період, а найголовнішим завданням у цей час стало встановлення військової організації, притаманній частинам УГА. Вже в травні 1921 р. у таборі був сформований старшинський курінь (командант - майор Омелян Лисняк, ад’ютант - поручик Володимир Федак) у складі двох старшинських сотень (командант 1-ої сотні - сотник Фердинанд Балицький, 2-ої - сотник Остап Кравець), стрілецька сотня (поручик д-р Михайло Гринів), відділ жандармерії (поручик Юрій Ковалюк). До складу 1-ої сотні увійшли старшини з групи генерала Кравса, до 2-ої - з інших підрозділів Армії УГА, які у 1919 р. відступили на територію ЧСР (цей поділ на вимогу чехословацької влади було запроваджено ще в Ліберцях).

Також було утворено українську команду табору на чолі з полковником Арнольдом Вольфом, який став «безпосереднім зверхником всіх українців тільки під організаційним оглядом і підлягав як такий прямо чсл. (чехословацькій - I. С.) команді збірного табора». Йому допомагали ад'ютанти (перший - сотник Іван Козак, другий - поручик Василь Кузьмин), а також хорунжий Іван Шебуньчак (помічник ад’ютанта), поручик Ярема Хоміцький («харчовий» старшина), хорунжий Михайло Романишин («складовий» старшина), вахмістр 2-го класу Евбезій Арійчук («булавний справник») (діловод - I. С.). Команда щоденно призначала чергового старшину та підстаршину в таборі для виконання інспекційних функцій, вартових (один підстаршина та шість стрільців) на вході до табору на цілодобове чергування, а також у таборовій «лічниці» (лікарні - I. С.). Спочатку вартовим видавалась зброя - гвинтівки з багнетами без набоїв, проте на початку липня від такої практики чехословацька комендатура вирішила відмовитись ${ }^{34}$.

Надзвичайно важливим завданням, яке з самого початку існування табору вимагало негайного вирішення з боку команди табору, було встановлення та підтримання високого рівня дисципліни серед інтернованих, бо тільки за такої умови можна було сподіватись об'єднати таборян та зберегти військові традиції УГА у досить складних умовах таборового існування. В цій ситуації полковник А. Вольф запропонував утворити в таборі постійну дисциплінарно-слідчу комісію, проект якої було розроблено генералом А. Кравсом. Потреба в ній обумовлювалась тим, що у таборі трапилось кілька випадків, «яких не можна полагодити ані дисциплінарною, ані честирадною дорогою» ${ }^{35}$. Тому вже 3 березня $1921 \mathrm{p}$. наказом команданта табору (ч. 2653) була створена Слідча комісія (голова - четар д-р Іван Мельницький, правничий референт - поручик Володимир Яворський $)^{36}$.

У цей час частина інтернованих старшин УГА справедливо нарікала на складні умови таборового повсякдення, при чому особливо потерпали ті, хто мав родини: нарешті, їх гнітила відсутність чіткої перспективи у подальшому, бо шлях додому для них був закритий. Все це посилювало внутрішнє незадоволення та призводило до чвар, суперечок і конфліктів здебільшого на побутовому грунті. На нездорову ситуацію, яка витворилась між деякими старшинами, звернув увагу один з булавних старшин табору - майор Омелян Лисняк, котрий у своєму рапорті (від 5 червня 1921 р.) до команди табору зауважив 
збільшення числа «афер між старшинами». Уважне вивчення протоколів досудового розслідування таких конфліктів дозволило йому прийти до висновку, що їх причинами було «нерозуміння точного становища старшини, брак виховання військового, незнання приписів та легковаження наслідків». Це у свою чергу призводило до таких негативних явищ у старшинському середовищі як «лайки, обкидування себе безпідставними закидами, обопільні безпідставні обжалування (скарги - I. С.), які в кінці майже завсігди доводять до такого хаосу, що годі їх розібрати» ${ }^{37}$.

На думку майора О. Лисняка, «справдішній старшина не повинен ніколи забувати на своє становище у війську і суспільности», попри те, в яких би він обставинах не опинився, і чим складніші вони, тим гідніше має поводитись старшина. Але «деструктивний вплив війни, надплив в старшинський корпус єлементів всякої якости, [...] брак наслідків за прогріхи і вини, [...] заборону двобою (дуелей - I. С.) відняли старим воєнним постановам цілу силу дисциплінуючу і моральну», призвівши до того, що непослух став ледь не загальним явищем у військовому середовищі, у т.ч. й серед українського старшинства. Все це переконало його у доцільності застосування «радикальніших средств» до порушників дисципліни у випадку відмови від виконання наказів, а саме попередження про «деградацію» (розжалування - I. С.) старшини за «трикратний непослух», і власне «деградацію» до степеня стрільця у разі чергової відмови виконувати наказ. У виключних випадках вже «раз поповнений злочин повинен вже віддати винного справедливій хотя й строгій карі» ${ }^{38}$.

Крім того, для оздоровлення внутрішньотаборових відносин майор О. Лисняк пропонував організувати «виклади про добрий тон» $\mathrm{i}$ «виклади про поведення в справах честі» для трьох сторін - «ображеного» старшини, «визваного» (того, що образив - I. С.) i секунданта. Свої міркування О. Лисняк передавав на розгляд «нашим булавним старшинам, судам чести та таборовому судови», і за умови їх схвалення вони мали стати ефективним запобіжником відцентровим процесам у середовищі старшинства УГА. Проте втілити в життя пропозиції О. Лисняка було дуже складно, і в першу чергу внаслідок того, що чехословацька влада вважала за доцільне передати інтернованих українці під юрисдикцію своїх судових органів. Тому вже в середині червні 1921 р. на вимогу Міністерства народної оборони ЧСР військовий суд УГА було ліквідовано як інституцію, що у свою чергу обмежило повноваження українського команданта табору Йозефов.

Намагаючись мінімізувати можливі негативні наслідки цього команда табору доклала всіх зусиль для створення на початку липня 1921 р. двох «честирадних виділа» (постійно діючих виборних представництв старшинських судів честі - I. С.), завданням яких стало розслідування всіх проступків старшин з подальшим їх розглядом старшинським судом честі за участі всіх присутніх у таборі старшин відповідної сотні. Як йшлося в «довірочному» рапорті першого ад'ютанта українського коменданта табору сотника I. Козака про внутрішню організацію табору Йозефов до військової канцелярії Диктатора ЗУНР у Відні (ч. 469 від 30 липня 1921 р.), «при великім числі афер, які є в таборовім життю неминучі», суди честі були одним з найефективніших інструментів підтримання карності та військового порядку в таборі. «Виділи» складались 39 осіб (три члени, перші та другі їх заступники, загалом - шість осіб) та один «протоколянт» і два його заступники ${ }^{39}$.

Додатковим мобілізуючим старшин чинником було перебування у таборі генерала А. Кравса (як старший за військовим званням саме він мав стати командантом табору, але 3 огляду на те, що чехословацьким комендантом був полковник, А. Кравс не вважав для себе за можливе виконувати ці обов'язки). На виконання розпорядження військової канцелярії «довірочним» наказом (ч.1575) була також створена Комісія для перевірки старшинських степенів (голова - майор Роман Волощук), завданням якої було вивчення документів старшин про присвоєння їм всіх старшинських звань ${ }^{40}$.

Про ефективність іiї діяльності свідчить хоча б справа лікаря Гаврилціва, якого було відряджено до табору за розпорядженням військового відпоручника Диктатора ЗУНР. Комісія встановила, що «він не лише не $є$ ніяким лікарем, але навіть не називаєся «Гаврилців», та в ріжних часах і місцях виступав під всілякими іменами, хоч до цего не був ніякими політичними обставинами приневолений». Врешті-решт, йому не залишалось нічого кращого, як зголоситись до повороту на більшовицьку Україну та виїхати в липні 1921 p. до УСРР ${ }^{41}$.

До того ж, 1 серпня 1921 р. у таборі були арештовані кілька вояків УГА, які проводили більшовицьку агітацію. Того самого дня українським командуванням було розпочато 
слідство в цій справі та «зібраний вельми обширний матеріал», про що було повідомлено i чехословацькій комендатурі ${ }^{42}$. Це був непоодинокий випадок - у проведенні більшовицької пропаганди були звинувачені та перебували під слідством поручик Ващук, хорунжий Яблонський, підхорунжий Яцушко, вістун Делеш, стрілець Слука ${ }^{43}$. На жаль, неправдиві інформації більшовицьких агітаторів інколи змушували частину інтернованих сприймати ïx «за чисту монету». Так, зокрема, поголоски про можливе перенесення інтернованих 3 табору Йозефов до Кенігсбергу навіть спонукали полковника А. Вольфа звернутися на початку серпня 1921 р. до української команди в Німецькому Яблонному аби переконатись в їх безпідставностін

Ще одна група старшин (майор Ф. Лянг, сотник Купчанко, поручик Ліщинський, четар Петрикевич, хорунжий Рачинський, четар Корецький) підозрювались у побитті поручика Райха, майор Шашкевич - у співучасті в крадіжці (останнє не було доведено, після чого слідство проти нього було призупинено). Нарешті за вироком міського суду в Яромеже до різних термінів ув'язнення були засуджені четар Приставський і хорунжий Гембарський (співучасть у спротиві владі) ${ }^{45}$.

Дещо порушуючи хронологію викладу подій слід зазначити, що взимку порушення дисципліни почастішали, внаслідок чого «честирадні виділи» працювали зі значним навантаженням: у березні 1922 р. вони провадили слідчі справи щодо 40 старшин та 5 хорунжих. Окремо слідча комісія вивчала справи 32 старшин, 9 хорунжих, 55 підстаршин та стрільців (загалом - 96 справ). У переважній більшості воякам закидались такі звинувачення: «взаємна особиста обида» (образа - I. С.), «нестаршинське поведення», «взаємна зневага» (у старшин); «самовільне віддалення» (залишення табору чи робітничої команди - I. С.), «спроневірення» (невиконання наказів - І. С.), «крадіжки», «побиття в часі забав» ${ }^{46}$.

Але найнагальнішою залишалась справа підготовки бараків до зими. Вже вкотре сотник I. Козак звертався зі «строго довірочним» рапортом (ч. 279/2 від 23 серпня 1921 р.) до військової канцелярії Диктатора ЗУНР в Празі, в якому наголошував на потребі проведення робіт з утеплення бараків шляхом зведення в них додаткових внутрішніх стін та заповнення міжстінного простору соломою. 3 огляду на те, що чехословацькою владою вже було ухвалене рішення про залишення інтернованих українців у Йозефові на зимівлю, роботи слід було розпочати негайно. Ситуацію ускладнювало та обставина, що до Йозефова мала бути переведена і «Українська бригада» 3 табору в Німецькому Яблонному ${ }^{47}$.

Для проведення цих робіт був утворений спеціальний будівельний відділ, але він фактично не приступив до роботи, бо не мав для цього відповідних вказівок. Таборова чехословацька комендатура так само не докладала жодних зусиль для організації не те що утеплення, але навіть тривалий час не робила анічого аби «полатати на осінь дах, який діравий наче сито». На думку полковника Залєського, залишати на зимівлю інтернованих в Йозефові було цілком неможливою справою, у зв'язку з чим він подав відповідний рапорт про необхідність інспектування спеціальною комісією бараків табору та ухвалення рішення про доцільність переведення українських вояків до інших казарм. Свою думку він обгрунтовував тим, що за весь час перебування тут полонених росіян від холоду та хвороб вмерло близько 17 тис. чол. Справа в тім, що зима в цій місцевості є безсніжною, 3 сильними морозами та вітрами, відтак навіть у бараку чехословацької комендатури, який $\epsilon$ добре огріваним, «через зиму так студено, що мимо безнастанного топлення без кожуха не можна було там висидіти», а що вже говорити про «звичайні» бараки... ${ }^{48}$.

Отже, у тому випадку якщо вже ж таки інтерновані залишались в Йозефові, слід було збудувати нові бараки, бо це виявилося б дешевше, ніж переобладнувати старі приміщення, збудовані ще за австрійських часів. Проте Міністерство народної оборони ЧСР не вважало за потрібне виділяти кошти ані для будівництва чогось для інтернованих, ані для ремонту майже цілком знищених бараків. Небажання чехословацької влади забезпечити прийнятні побутові умови в таборі «викликали страшний занепад духа, що граничить майже $з$ панікою», у його мешканців; більша частина «старшин, передовсім старших віком і 3 надірваним здоров'ям, стараються за всяку ціну вирватись заздалегідь 3 табора, щоби лише тут не зимувати» ${ }^{49}$.

Але навіть вийшовши з табору та влаштувавшись на роботу в Прикарпатській Україні галичани постійно перебували під загрозою ії̈ втрати через постійні протести польської влади, яка вбачала в цьому недружні для себе кроки Праги. Все більше старшин звертались до команди 3 проханнями надати їм безстрокову відпустку, а решта демонстрували 
«велику знеохоту і розпучливу майже резигнацію», а у декого навіть з'являлись думки вдатись до підпалу табору, чому досить ефективно намагалась запобігти команда табору ${ }^{50}$.

Сотник I. Козак припускав, що таке неприхильне ставлення чехословацької влади до інтернованих пояснювалось тодішнім чесько-польським політичним зближенням, а також намаганням «спровокувати якийсь нерозважливий крок з боку наших частин, щоби відтак мати привід до видання нас полякам». Це стало би справжньою катастрофою для інтернованих, і для уникнення такого розвитку подій Диктатурі ЗУНР пропонувалось «постаратись о перенесення наших частин до иншої держави». Зауважимо, що насправді Прага не мала таких планів, і ці побоювання таборян були безпідставними, крім того, здійснити переведення інтернованих до іншої країни було цілковито неможливим як через відсутність такої, так і з огляду на значні видатки для утримання таборів.

Насамкінець сотник I. Козак звертався з проханням здати в Ліберцях вугілля і дрова на військові склади, що уможливлювало би подання внесень на отримання такої самої кількості палива в Йозефові. Але найкращим виходом зі скрутної ситуації і «задля удержаня табора і цілости і охорони житя і здоровля останків У.Г.А.» він вважав розміщення інтернованих в кам'яних будівлях Липника, Пардубиць або Оломунца ${ }^{51}$.

За два дні перший ад'ютант коменданта табору знову звернувся 3 «довірочним» рапортом (ч. 334/1 від 25 серпня 1921 р.) до військової канцелярії Диктатора ЗУНР, в якому повідомляв про достатню кількість вільних бараків в одній із секцій табору - «Д», в яких можна було би розмістити до 1400 чоловік або 70 родин, 220 старшин і 600 стрільців. Проте в цій частині таборі продовжували перебувати 20 чол. репатріантів до Радянської України та чехословацький запасний батальйон, відтак передача цих бараків інтернованим українцям відбутися не могла ${ }^{52}$.

Внаслідок того, що Йозефов і надалі залишався збірною станицею для українських та російських репатріантів, які повертались до УСРР і РСФРР, чехословацька влада ігнорувала всі прохання таборового командування інтернованих військ УГА передати частину бараків для зручнішого розселення таборян. Так само нічого не робилось для підготовки бараків до зими, що створювало грунт для поширення в таборі занепадницьких настроїв, i сотник I. Козак вдруге нагадував, що булавні старшини прагнуть будь-що самовільно залишити табір, а дехто з молодших підносить думку про підпал бараків, коли би інтерновані не були переведені до іншого табору чи стаціонарних казарм. Взагалі, думка про необхідність «зимовання в тут[ушньому] таборі викликала свого роду паніку серед старшин» ${ }^{53}$, бо жодних робіт з адаптації бараків влітку так і не було проведено.

У своєму черговому «довірочному» рапорті сотник I. Козак (ч. 279/1 від 30 липня 1921 р.) знову і знову звертав увагу політичного проводу ЗУНР на те, що чехословацька влада досі не вжила жодних заходів аби підготували табір до зими. До всіх проблем, про які вже повідомлялось, останнім часом в таборі з'явились «страшні блощиці, так що майже половина старшин і стрілецтва спить на дворі, бо в бараках неможливо ізза цего [...] заснути». На думку I. Козака треба будь-що перенести табір, бо його залишення в Йозефові «на осінь без основної перебудови бараків, рівняло б ся засудови більшої части старшин і стрільців на смерть» ${ }^{54}$.

У цій ситуації інтерновані були змушені власними силами полагоджувати бараки, крім того українська команда табору сформувала невеликий робітничий відділ з числа таборян (стрільців), але останні працювали неналежно, «так що жителів табора в їх неоправлених бараках заскочила зима, яку ще не раз серед тут[ешньої] прочої загальної нужди годі пережити». Єдине, чим допомогла чеська комендатура табору, так це тим, що «забезпечила папу (толь, різновид рулонного покриття - I. С.) для покрівлі та дощок $з$ ліберецького табора для ремонту стін, проте самого ремонту не було проведено» ${ }^{55}$.

Очевидно, що такі невідрадні побутові умови дуже негативно позначались на моральному стані деяких інтернованих, які шукали собі розради в чарці, намагаючись у такий спосіб притлумити свої душевні страждання та тугу за Батьківщиною. Дезорганізуюче на таборян впливало й те, що в одному таборі, хоча й в різних його секціях, опинились різні категорії інтернованих, які суттєво відрізнялись нормами грошового забезпечення. Частина 3 них перейшли кордон ЧСР зі зброєю в руках, зберігши свою військову організацію (це т.зв. «кравсівці» та «брігадійці»). Вони утримувались спочатку у таборі Німецьке Яблонне (звідси їх сукупна назва - «габлівці»), а після їх перевезення до Йозефова восени 1921 р. ця категорія вояків була приміщена в секції «Б». Решта вояків-галичан, які прибули на те- 
риторію ЧСР поодинці чи групами з різних місць, перебували спочатку у таборі Ліберець, а після переїзду до Йозефова були скупчені в секції «Д».

Чисельний стан інтернованих українських військ в Йозефові становив (дані на 24 березня 1922 р.): в секції «Б» - 148 старшин та 630 стрільців (у т.ч. «бригадійців» - 81 старшина та 537 стрільців; «кравсівців» - 67 старшин та 93 стрільця). Кількість таборян у секції «Д» складала: 88 старшин, 188 стрільців, 48 одружених жінок, 17 жінок «вільного стану» і 41 дитина. У секції «Д» всі його мешканці отримували 0,5 Кс̌, робітничий додаток для всіх працюючих становив від 3,5 до 2 Кс̆; у таборі «Б» - денне утримання старшин становило 5 Кс̌ денно, підстаршин і стрільців - 0,5 Кс̌. Грошова квота для старшин в останньому випадку була достатньою для прожиття, крім того у разі їх залучення до робіт в складі робітничих сотень, старшини та стрільці отримували «робітничий додаток» (відповідно - 5 Кс̌ та від 3,5 до 2 Кс̌), що дозволяло нормально харчуватись та забезпечувати основні свої життєві потреби ${ }^{56}$.

Архівні документи свідчать, що цих коштів вистачало і на дещо інше, зокрема на пиятику. В рапорті четаря Григорія Горука до команди табору Йозефов від 4 жовтня 1921 р. йшлося про негідну поведінку групи старшин УГА (чотирьох «габлівців» і четаря Татоміра з Йозефова) днем раніше, які хоч і «були спиті мало [...] велися крайно не по старшинському». Один старшина взагалі був добряче напідпитку, бо «найбільше верещав і ледви на ногах тримався». В пошуках «сильних» розваг двоє 3 цієї групи «пішли під якийсь дім, думаючи правдоподібно що це якийсь дім публічний і почали так сильно до дверей гримати, що було чутно на цілу улицю» ${ }^{57}$.

Все це відбувалось на очах інтернованих та чехословацьких офіцерів, які вважали за краще не зачіпати цю групу нетверезих українських вояків, хоча останні при цьому вигукували лайливі слова на їх адресу. Наступним об’єктом їх зацікавлення стала таборова ресторація, в якій згадувані старшини «почали рівнож скандалити», ба більше - «вчіпилися кельнерки при гостях, щоби йшла з ними до сепаратки (окремої кімнати - I. C.), на що тамта не згоджувалась, кажучи що она не належить до того рода женщин» ${ }^{58}$. У своєму рапорті четар Г. Горук цілком слушне зазначав, що така поведінка «габлівських старшин підкопує нашу дотеперішню добру славу серед чеської публіки в Йозефові і може мати за собою ще гірші наслідки», з чим дуже складно не погодитись.

Справа в тім, що рівень грошового забезпечення таборян з секції «Д» забезпечував хіба що їх елементарні життєві потреби, але не більше того. Ця проблема весь час залишалась нездоланним завданням для команди табору, яка неодноразово зверталась у цій справі до політичного проводу ЗУНР, безпідставно сподіваючись, що останній зуміє переконати чехословацьку владу позитивно іiі вирішити. Скрута таборян з секції «Д» була такою, що ця категорія інтернованих була готова братись за будь-яку роботу, зокрема жінки вишивали, але це тільки іноді давало хоч якісь додаткові кошти для їх родин ${ }^{59}$. І ось саме на цьому тлі пиятика кількох старшин (в рапорті їх прізвища не названі) виглядала надто непривабливо, особливо якщо згадати, що на той час мінімальна денна сума для проживання в ЧСР, за визначенням команди табору, становила 1,5 Кс̌. Але виходило, що «габлівці» можуть собі дозволити значно більше - навіть відвідування ресторації та «сепаратку».

Ситуацію в таборі загострювали непорозуміння та навіть відкриті конфлікти між старшинами, що виникали на грунті особливого ставлення декого 3 них до одружених та неодружених жінок, які перебували в Йозефові. У цьому відношенні є досить промовистим рапорт команди табору (за підписом сотника I. Козака) до військової канцелярії Диктатора ЗУНР у Відні від 1 жовтня 1921 р. щодо звинувачень вдови Б. Вимєталь на адресу О. Морозової. Уважне вивчення цього документу дає підстави твердити, що першоосновою суперечок між згадуваними жінками стало «засвобідне поведення супроти мущин» останньої, та факти того, що «деякі старшини, навіть булавні, бувають у п[ані] Морозової та виступають 3 нею публічно». Внаслідок цього в стосунках з їі чоловіком (поручиком О. Трачем) доходило «до всіляких немилих сцен з плачем, спазмами і т.д.», і врешті-решт «один з таких інцидентів дав понуку до їх розлучення з боку команди табора» ${ }^{60}$.

Але найбільш обурювала Б. Вимєнталь та обставина, що О. Морозова не відчувала жодних матеріальних труднощів у таборі та завжди була «напарфумована і вимальована», натомість «п[ані] Вимєтальова і єї дитина босі та голі», проте за це не можна було винуватити команду табору, бо «ані на лихе матеріальне положення першої ані на корисну ситуацію другої» українська військова влада не впливала і не могла впливати. На 
думку команди табору, як О. Морозова, так і Б. Вимєталь «мали дуже погубний вплив на деяких старшин та стали причиною поділу табора на дві партії», і для нормалізації ситуації в Йозефові обох жінок разом з їх дітьми у вересні 1921 р. було переведено до іншої секції табору ${ }^{61}$.

У жовтні 1921 р., після переїзду до Йозефова Української Бригади з Німецького Яблонного, відбулись деякі зміни в організаційній структурі інтернованих українських частин, які (як вже зазначалось) перебували в двох окремих секціях табору («Б» $\mathrm{i}$ «Д»). Обидві секції підлягали дисциплінарній та адміністративній владі дотеперішнього команданта табору - полковнику А. Вольфу. В секції «Б» було утворено старшинську та стрілецьку сотні, які були безпосередньо підпорядковані команданту табору. Це було зроблено на прохання булавних старшин Української Бригади та її колишнього команданта майора Дрималика, котрі вважали, що така організація «буде дуже корисна для витвореня військового духа і єдности в обох таборах» та найкраще забезпечуватиме командну вертикаль.

У секції «Д» в організаційному відношенні було збережено курінну структуру (комендантом куреня на той час був майор Богуслав Шашкевич, сотні відповідно очолювали: 1-шу старшинську - сотник Корній Купчанко, 2-гу старшинську - сотник Едвард Геніг, 1-шу стрілецьку - поручик Василь Виноградник). Відбулись зміни і в складі команди табору: у зв'язку з отриманням студійної відпустки майором Фердинандом Валєком (заступник команданта) на цю посаду був призначений майор Омелян Лисняк.

Видається цікавим порівняти чинну організаційну структуру інтернованих українських військ у Йозефові з даними більшовицького агентурного зведення станом на кінець листопада 1921 р. На той час, за підрахунками радянських агентів, у таборі перебувало близько 1200 військовиків УГА (в т.ч. близько 500 старшин), які в організаційному відношенні поділялися на три групи: до першої групи входили вояки зі складу колишньої бригади генерала А. Кравса на чолі з майором Лесняком; основу другої утворила Українська бригада з Німецького Яблонного (комендант - отаман Дрималик); до третьої було зведено всіх утікачів 3 таборів Польщі та Італії (в тексті помилково Туреччини - I. С. $)^{62}$. Співставлення цих даних 3 дійсним станом справ дає підстави стверджувати, що більшовицька агентура знала про три складові частини українського вояцтва, що перебували в таборі. Крім того їм також були відомі прізвища декого з чільних старшин інтернованих, проте детальна організаційна структура українських військ залишались для них таємницею.

На початку грудня 1921 р., після закінчення переведення до Йозефова всіх вояків УГА, інтернованих було поділено на чотири (1-шу і 2-гу старшинські та 3-тю і 4-ту стрілецькі) сотні $^{63}$. Комендантом табору і надалі залишався полковник А. Вольф, який відповідно до наказу команди УГА в Німецькому Яблонному (перед ліквідацією цього табору) отримав «карно-дисциплінарну» владу над усіма українськими військовиками в ЧСР, що перебували у таборі Йозефов або працювали у складі робітничих команд. До Йозефова було переведено й спеціальні інституції Української бригади у Німецькому Яблонному (слідчу комісію, старшинський суд честі, референтуру особистих справ та ін.), які дещо пізніше було розв'язано. Сюди ж було перевезено і все майно Української бригади, у тому числі склад одностроїв та «Український державний фонд бригади», який було створено шляхом продажу цих одностроїв старшинам УГА ${ }^{64}$.

Взимку 1921-1922 рр. відбулись деякі зміни у персональному складі команди табору після отримання сотником I. Козаком студійної відпустки та полишення ним табору для продовження навчання: першим ад'ютантом команданта табору було призначено сотника Тому (Фому) Котика, ще одним ад’ютантом став поручик Володимир Федак. Було також призначено «перзонального» референта (ним став поручик Ярослав Пастернак) i «евіденційного» старшину (поручик Антін Дацків). Час від часу змінювались і команданти сотень: в березні 1922 р. у секції «Б» провід старшинською сотнею здійснював майор Роман Волощук, стрілецькою - сотник Адольф Альтшілєр; командантом секції «Д» був майор Михайло Дибуляк, старшинської сотні - сотник Едвард Геніг, стрілецької - поручик Семен Сак ${ }^{65}$.

Крім того команді табору підлягали «Полевий духовний уряд» (душпастирство) на чолі з о. Михайлом Кушкевичем, таборовий лікар сотник Микола Кметь, який також був й начальником таборової лічниці («приюту хорих»), Термінологічна комісія (голова майор Фердинанд Лянг). Як окремі військові інституції в таборі існували: слідча комісія, сотенні «честирадні виділи», Комісія для перевірки ступенів (про них вже йшлося вище). Нале- 
житься згадати також про Економічно-адміністративну комісію (наказ ч. 3501 від 9 грудня 1921 р.), запомогову інституцію «Самопоміч» (голова сотник Василь Чарнецький) та Культурно-Просвітній Кружок (голова - четар д-р Іван Мельницький) ${ }^{66}$. Нарешті, команді табора підлягали робітничі команди, сотні та відділи, які працювали поза табором - в різних містах та місцевостях ЧСР.

Зима 1921-1922 рр. стала одним з найскладніших випробувань вояцтва УГА на вірність національним ідеалам, бо у цей час спостерігалося «зовсім недвозначне стремління чеської влади покласти край своїй гостинності» ${ }^{67}$. Загальну картину стану бараків та санітарної ситуації в таборі можна відтворити за звітами та рапортами таборового лікаря та сотенних командирів, що подавались команді табору Йозефов навесні-влітку 1922 р., знов таки, з метою привернути увагу чехословацької влади до часом драматичних реалій таборового життя інтернованих вояків-українців та запобігання їх повторенню у наступну зиму.

Оцінюючи наявний стан бараків у Йозефові в березні 1922 р., таборовий лікар д-p М. Кметь у своєму «санітарному звіті» зазначав, що вони є «старі, понищені, примітивні, не гигієнічні. Загально протікають через знищену стріху, а через дрантиві стіни 3 дощок провіває вітер ${ }^{68}$. Навіть важко собі уявити, як мешкали, точніше виживали, інтерновані у січні-лютому 1922 р. під час сильних морозів та вітрів. Не всі бараки встигли переобладнати для проживання старшин та родин, стрільці, зокрема, мешкали у необлаштованих бараках, в яких і в погожий сонячний день була напівтемрява.

Дуже складною була й загальна санітарна ситуація в таборі. До бараків так і не був підведений водогін, що створювало додаткові проблеми 3 підтриманням в них чистоти. Не дотримувались й елементарні умови особистої гігієни у бараках - «стрільці не мають зовсім простирал, а підстаршини тілько по однім». При цьому «стрільці мають переважно по одній парі біля і то підраного», гостро бракувало й взуття, внаслідок чого «часто значна часть стрілецтва ходить боса». Крім того, таборяни за весь час перебування у таборі в осінньо-зимовий період не мали можливості прийняти «купель» (ванну - I. С.). Але найдошкульнішим для таборян (особливо для жінок і дітей) було те, що поза бараками розміщувались т.зв. «лятрини» (похідні туалети, фактично майже нічим необлаштовані ями для задоволення природних потреб - I. С.) ${ }^{69}$.

Відтак не слід дивуватись тому, що стан здоров'я інтернованих в таких умовах існування був зовсім не задовільним, зокрема частина вояків страждала на «чахотку легких (легень - I. С.), яка тут знайшла умовини пригожі до дальшого розвою, а якій початок дали труди і злидні світової війни». Через низьку температуру в бараках дуже поширеним явищем у інтернованих були простудні хвороби, і зокрема, «інфлюєнція, яка поширилась в зимі з браку опалу (3 сотня не мала через 10 днів під час морозів вугля)». Ще однією дошкульною проблемою було «значне число полових недуг, переважно старих (рецидив)» у частини таборян, але у цьому випадку дехто з них міг сподіватись на лікарську допомогу під час стаціонарного лікування в спеціалізованих чеських лікарнях. Але попри такий стан д-р М. Кметь констатував «малий рівень смертності» ${ }^{70}$, що дозволяє зробити висновок про високу здатність таборян переборювати життєві труднощі та їх забезпеченість достатнім «щодо якости і скількости» харчовим пайком.

Фактично внаслідок незадовільного опалення бараків померла дитина старшого десятника Лазурка, а в серпні 1922 р. в дивізійному шпиталі через ускладнення від перенесених хвороб та отриманих поранень пішли 3 життя ще троє таборян, у т.ч. хорунжий Вишинський (3 діагнозом: «чахотка та виснаження від таборового життя»). Попри дійсно невеликі абсолютні цифри померлих, багато хто з «стрільців, і навіть старшин вважав себе забутим і полишеним власній судьбі» ${ }^{71}$.

Рапорти командирів підрозділів почастішали в серпні 1922 р., бо знову наближалась осінь, а за нею зима, а бараки продовжували залишатись фактично у минулорічному стані. 3 рапортів сотенних унаочнюється сумна, а часом трагічна побутова ситуація, котра витворилась у таборі. Так, зокрема, вояки 2-ої сотні мешкали в бараках, що були збудовані «з сирого матеріалу, який по кількох літах зсохся і через се повстали прогалини, які місцями доходять навіть до ширини 6 цм (сантиметрів - I. С.), а підлоги і дахи [...] перегнилі». Під підлогою «знаходиться порожня - яка уможливлює се, що вітри через підлогу дістаються до кімнати». Покрівля даху настільки «перегнила і місцями повідривана вітрами і внаслідок сего в часі дощу мешканці $є$ приневолені не раз серед ночи переноситись 3 місця на місце». Найгіршим було те, що утеплення бараків «вимагало 
би цілковитої перебудови і великого вкладу, який перевисшав (перебільшував - I. С.) би теперішню вартість бараків» ${ }^{72}$.

На додаток до усього цього якість вугілля «було найгіршого сорта і по більшій части саме сміття, яке не хотіло горіти і не виділяло жодного тепла». Тому температура в кімнатах 4-го бараку була часом від мінус трьох до -23 градусів, «вода постійно замерзала». Щоб якось собі зарадити інтерновані на власний кошт докуповували вугілля, крім того у цьому таборянам частково допомагала таборова «Самопоміч». Але попри всі ці заходи вояки продовжували мерзнути в бараках, i, як наслідок, застуджувались, після чого переводились до гарнізонної лікарні. Діти «цілу зиму пролежали в завитях (загорнуті - I. С.) в ліжку». Але випадків смерті від переохолодження не було ${ }^{73}$.

У рапорті командира 3-ої сотні міститься інформація про те, що внаслідок низької температури у бараках стрільці мерзли, і понад 150 осіб з їх числа застудились та захворіли на грип, а крім того «було кілька легких відморожень ніг»; у рапорті командира 4-ої сотні повідомляється про один випадок смерті малої дитини, яка вмерла через переохолодження ${ }^{74}$. Не була кращою ситуація і в бараках старшинської сотні, хоч тут у кожній кімнаті була встановлена піч, довкола якої «трохи тепло, коли палиться». Але вже за кілька метрів від неї замерзала вода. Тому не $є$ дивним, що два старшини відморозили собі пальці під час спання, значна кількість хворіла на застуди. 3 огляду на це командир старшинської сотні робив висновок, що «здатність бараків до перезимування в р[оці] 1922/23 неможлива, бо бараки старі, а тамтогорічна направа (минулорічний ремонт - aвm.) в наслідок частих дощів не причиняєсь до поліпшення їх стану» ${ }^{75}$.

14 серпня 1922 р. таборовий лікар д-р Кметь наново звернувся з рапортом до команди табору, в якому ще раз оцінив стан бараків, дошки яких «пігнили, потрупішали, повідсувались від себе і через се втратили свою первісну охороняючу вартість аж до $50 \%$ ». На його думку, було очевидним, що «в того рода бараках збільшування опалу $є$ не доцільне, бо огрітий воздух сейчас улітає прогалинами з кімнат». Він стверджував, що температура «в бараках була серед зими велика понад $-15^{\circ} \mathrm{C}$, що було причиною багато захворінь ревматичних, інфлюєнційних, запалень олегочної (легеневих - I. С.), а у багатьох значного погіршення загального стану здоровля ${ }^{76} .3$ огляду на те, що причиною цих хвороб був, на його думку, незадовільний стан бараків, він пропонував не наражати інтернованих на розпачливу перспективу ще одного перезимування в них, а докласти всіх зусиль до переведення таборян до стаціонарних казарм.

Але як і рік тому, чехословацька влада не збиралась утеплювати бараки, вважаючи, що проблема інтернованих буде невдовзі вирішена. Відтак таборяни знову мусили власними силами ремонтувати покрівлю бараків, затикати розсохлі щілини в їх стінах, утеплювати підлогу (якщо мали відповідні матеріали). Змушуючи таборян до цього, офіційна Прага фактично заохочувала українців до залишення таборів та їх переходу на цивільний стан, бо утримання інтернованих підрозділів УГА вносило певну напругу в чесько-польські міждержавні відносини, а також збільшувало обсяг непродуктивних видатків з бюджету ЧСР.

Тому вживане у багатьох наукових публікаціях (у т.ч. й автора цієї статті) твердження про «прихильно-доброзичливе» ставлення влади ЧСР до інтернованих на ії теренах вояків УГА вимагає суттєвого уточнення. Не заперечуючи його в засаді, бо українці дійсно мали можливість жити в таборах власним національним життям, у разі потреби їм надавалась кваліфікована медична допомога в чеських лікарнях (стаціонарне лікування), нарешті, після залишення табору вчорашні інтерновані могли здобувати цивільний фах за власним вибором в чеських університетах та вищих школах за досить ліберальних умов (українські студенти мали достатній термін для адаптації та прихильне ставленням 3 боку чеської професури, а також отримували стипендіï), слід натомість зауважити, що побутові умови перебування українського вояцтва в бараках, особливо в зимовий період, ставили таборян у надзвичайно скрутне становище.

Попри всі побутові складнощі та невизначеність своєї подальшої долі інтерновані в ЧСР вояки УГА продемонстрували свою незламну вірність ідеї національно-державного самовизначення України. Їх перебування у таборах стало своєрідним протестом-запереченням акту приєднання Польщею Західної України; разом з тим в середовищі таборян знаходила підтримку нова визвольна концепція, яка реалізувалась у кінці 1920-х рр. у вигляді організованого націоналістичного руху. 
${ }^{1}$ Наріжний С. Українська еміграція. Культурна праця української еміграції між двома Світовими війнами. - Прага, 1942. - Ч. 1. - 372 с.

${ }^{2}$ Його ж. Українська еміграція. Культурна праця української еміграції 1919-1939 (Матеріали, зібрані С. Наріжним до частини другої). - К., 1999. - 272 с.

${ }_{3}^{3}$ Павленко M.I. Українські військовополонені й інтерновані у таборах Польщі, Чехословаччини та Румунії: ставлення влади і умови перебування (1919-1924рр.). - К., 1999. - 352 с.

${ }^{4}$ Срібняк I. Український військовий табір УГА в Йозефові (Чехословаччина) у 1921-1924 pp. / I. Срібняк, А. Купцов // Воля і Батьківщина. - Львів, 1998. - Ч. 4 (13/29). - С. 65-78; Вони ж. 3 історії культурно-освітньої роботи у таборі інтернованих військ УГА в Йозефові (1921-1922рp.) // IV Міжнародний конгрес україністів (Одеса, 26-29 серпня 1999 р.): Доповіді та повідомлення. Історія. - Частина 2: XX століття / Міжнар. асоц. україн. - Одеса-Київ-Львів, 1999. - С. 423-429; Срібняк I.B. Українці на чужині. Полонені та інтерновані вояки-українців у країнах Центральної та ПівденноСхідної Європи: становище, організація, культурно-просвітницька діяльність (1919-1924рр.). - К., 2000. $-323 \mathrm{c}$.

${ }^{5}$ Українська політична еміграція 1919-1945: Документи і матеріали. - К., 2008. - 928 с.

6 Українська політична еміграція 1919-1945: Документи і матеріали. - К., 2008. - С. 128-129, $151-152,156-157,204$.

${ }^{7}$ Ямкова О.М. Культурно-просвітницька діяльність та національно-патріотичне виховання у таборах інтернованих українців у Чехословаччині // Вісник Київського національного університету імені Тараса Шевченка. Серія «Історія». - К., 2004. - Вип. 74-76. - С. 56-59; Фуртес О.О. Військова еміграція у боротьбі за державність - URL: ena.lp.edu.ua:8080/bitstream/ntb/10886/1/42.pdf (дата звернення - 03.09.2015).

8 Центральний державний архів громадських об’єднань України (далі - ЦДАГО України), ф. 269 , оп. 1, спр. 131, арк. 53.

${ }^{9}$ Там само, ф. 269, оп. 1 , спр. 131 , арк. 53-53зв.

${ }^{10}$ Там само, ф. 269, оп. 1, спр. 131, арк. 53зв.

11 Досить промовистим був й той факт, що лише протягом березня 1921 р. - у зв'язку з майбутнім переїздом до Йозефова - табір в Ліберцях самовільно залишило (фактично - дезертирувало) до 50 вояків УГА, У т.ч. 10 старшин - авт. (див.: ЦДАГО України, ф. 269, оп. 1, спр. 131, арк. 55зв.).

${ }^{12}$ ЦДАГО України, ф. 269, оп. 1, спр. 131, арк. 53зв.

${ }^{13}$ Там само, ф. 269, оп. 1, спр. 131, арк. 54зв.

${ }^{14}$ Там само, ф. 269, оп. 1, спр. 131, арк. 53зв.-54.

${ }^{15}$ Там само, ф. 269, оп. 1, спр. 131, арк. 54.

${ }^{16}$ Там само, ф. 269, оп. 1 , спр. 131, арк. 54-54зв.

${ }^{17}$ Там само, ф. 269, оп. 1, спр. 131, арк. 543в.-55.

${ }^{18}$ Там само, ф. 269, оп. 1 , спр. 131, арк. 55-55зв.

19 Там само, ф. 269, оп. 1, спр. 131, арк. 55зв.- 56.

${ }^{20}$ Там само, ф. 269, оп. 1, спр. 131, арк. 56.

${ }^{21}$ Там само, ф. 269, оп. 1 , спр. 131, арк. 72-72зв.

${ }^{22}$ Там само, ф. 269, оп. 1, спр. 131, арк. 72.

${ }^{23}$ Там само, ф. 269, оп. 1, спр. 131, арк. 120.

${ }^{24}$ Там само, ф. 269, оп. 1, спр. 131, арк. 72зв.-73.

${ }^{25}$ Там само, ф. 269, оп. 1, спр. 131, арк. 72зв.-73.

${ }^{26}$ Там само, ф. 269, оп. 1, спр. 131, арк. 106.

${ }^{27}$ Там само, ф. 269, оп. 1, спр. 131, арк. 106.

${ }^{28}$ Там само, ф. 269, оп. 1, спр. 131, арк. 106-106зв.

${ }^{29}$ Там само, ф. 269, оп. 1, спр. 131, арк. 106зв. Авторові не вдалось перевірити достовірність зазначеної тут кількості померлих полонених царської армії, цілком можливим є її завищення з метою привернення уваги Диктатури ЗУНР до незадовільного санітарного стану інтернованих вояків УГА в цьому таборі - И. С.

${ }^{30}$ Там само, ф. 269, оп. 1, спр. 131, арк. 106зв.

${ }^{31}$ Там само, ф. 269, оп. 1, спр. 131, арк. 107.

${ }^{32}$ Там само, ф. 269, оп. 1, спр. 131, арк. 119.

${ }^{33}$ Там само, ф. 269, оп. 1, спр. 131, арк. 149зв.

${ }^{34}$ Там само, ф. 269, оп. 1, спр. 131, арк. 125, 132.

${ }^{35}$ Там само, ф. 269, оп. 1, спр. 131, арк. 131.

${ }^{36}$ Там само, ф. 269, оп. 1, спр. 132, арк. 35зв.

${ }^{37}$ Там само, ф. 269, оп. 1, спр. 131, арк. 94.

${ }^{38}$ Там само, ф. 269, оп. 1, спр. 131, арк. 94-94зв.

${ }^{39}$ Там само, ф. 269, оп. 1, спр. 131, арк. 132зв., 116.

${ }^{40}$ Там само, ф. 269, оп. 1, спр. 132, арк. 35зв.

${ }^{41}$ Там само, ф. 269, оп. 1, спр. 131, арк. 133.

${ }^{42}$ Там само, ф. 269, оп. 1, спр. 131, арк. 135-135зв., 151. 
${ }^{43}$ Там само, ф. 269, оп. 1, спр. 132, арк. 138.

${ }^{44}$ Там само, ф. 269, оп. 1, спр. 131, арк. 138.

${ }^{45}$ Там само, ф. 269, оп. 1 , спр. 132, арк. 137, 138.

${ }^{46}$ Там само, ф. 269, оп. 1, спр. 132, арк. 36, 41.

${ }^{47}$ Там само, ф. 269, оп. 1, спр. 131, арк. 155.

${ }^{48}$ Там само, ф. 269, оп. 1, спр. 131, арк. 155-155зв.

${ }^{49}$ Там само, ф. 269, оп. 1, спр. 131, арк. 1553 в.

${ }^{50}$ Там само, ф. 269, оп. 1, спр. 131, арк. 1553в.-156.

${ }^{51}$ Там само, ф. 269, оп. 1, спр. 131, арк. 156

${ }^{52}$ Там само, ф. 269, оп. 1, спр. 131, арк. 159.

${ }^{53}$ Там само, ф. 269, оп. 1, спр. 131, арк. 159.

${ }^{54}$ Там само, ф. 269, оп. 1, спр. 131, арк. 130.

${ }_{55}^{55}$ Там само, ф. 269, оп. 1, спр. 132, арк. 104-104зв.

${ }^{56}$ Там само, ф. 269, оп. 1 , спр. 132, арк. 35зв.-36.

${ }^{57}$ Там само, ф. 269, оп. 1, спр. 131, арк. 186.

${ }^{58}$ Там само, ф. 269, оп. 1, спр. 131, арк. 186-186зв.

${ }^{59}$ Там само, ф. 269, оп. 1 , спр. 132, арк. 36.

${ }^{60}$ Там само, ф. 269, оп. 1, спр. 131, арк. 183-184.

${ }^{61}$ Там само, ф. 269, оп. 1, спр. 131, арк. 184-185.

${ }^{62}$ Сводка агентурных сведений о состоявшейся в Праге конференции кубанских политических и общественных деятелей и об интернированных украинцах в Чехии от 28 ноября 1921 г. // Русская военная эмиграция 20-х - 40-х годов. Документы и материалы. - Москва, 1998. - Т. 1: Так начиналось изгнанье 1920-1922 гг. - Кн. 2: На чужбине. - С. 446.

${ }_{63}^{63}$ Центральний державний архів вищих органів влади та управління України (далі - ЦДАВО України), ф. 3520, оп. 2, спр. 1, арк. 10.

${ }^{64}$ Там само, ф. 3521, оп. 2, спр. 1, арк. 1; оп. 1, спр. 11, арк. 6; ф. 3520, оп. 2, спр. 1, арк. 11.

${ }^{65}$ ЦДАГО України, ф. 269, оп. 1, спр. 132, арк. 35.

${ }^{66}$ Там само, ф. 269, оп. 1, спр. 132, арк. 35-35зв. - C. 10 .

67 Звіт праці Виділу секцій, курсів і установ... // Український Скиталець. - Йозефов, 1921. - Ч. 12.

${ }^{68}$ ЦДАГО України, ф. 269, оп. 1, спр. 132, арк. 39.

${ }^{69}$ Там само, ф. 269, оп. 1, спр. 132, арк. 39.

${ }^{70}$ Там само, ф. 269, оп. 1, спр. 132, арк. 39.

${ }^{71}$ Там само, ф. 269, оп. 1, спр. 132, арк. 104зв.

${ }^{72}$ Там само, ф. 269, оп. 1, спр. 132, арк. 81.

${ }^{73}$ Там само, ф. 269, оп. 1, спр. 132, арк. 81зв.-82.

${ }^{74}$ Там само, ф. 269, оп. 1, спр. 132, арк. 72, 853в.

${ }^{75}$ Там само, ф. 269, оп. 1, спр. 132, арк. 88.

${ }^{76}$ Там само, ф. 269, оп. 1, спр. 132, арк. 89. 